DOI: https://doi.org/10.24127/ajpm.v10i3.3897

\title{
CREATIVITY IN SYNCHRONOUS AND ASYNCHRONOUS LEARNING DURING THE COVID-19 PANDEMIC: A CASE STUDY
}

\author{
Muhammad Muzaini $^{1 *}$, Sri Rahayuningsih ${ }^{2}$, Nasrun $^{3}$, Muhammad Hasbi ${ }^{4}$ \\ 1* Mathematics Education, Universitas Cokroaminoto Palopo, Palopo, Indonesia \\ ${ }^{2}$ Mathematics Education, STKIP YPUP, Makassar, Indonesia \\ ${ }^{3}$ Department of Primary School Teacher Education, Universitas Muhammadiyah \\ Makassar, Makassar, Indonesia \\ ${ }^{4}$ Fakulty of Tarbiyah and Teacher Training, Institut Agama Islam As'adiyah Sengkang, \\ Sengkang, Indonesia \\ *Corresponding Author, Jalan Sungai Pareman Kel. Sabbangparu, 91913, Palopo, Indonesia

E-mail: $\frac{\frac{\text { muhammadmuzaini@uncp.ac.id }}{\text { srirahayuningsih86@gmail.com }}^{\left.{ }^{*}\right)}}{{ }^{2)}}$

Received 01 July 2021; Received in revised form 13 September 2021; Accepted 28 September 2021

\begin{abstract}
The corona virus outbreak has forced all universities to conduct learning online using the internet. We have considered to develop students' creativity through online learning. We therefore applied synchronous learning and asynchronous learning methods in the classroom and observed how these methods influenced students' creativity. Purposive sampling technique was used to select one out of 40 students from the Department of Mathematics Education at STKIP YPUP to participate in this study. The subject was chosen because he had fulfilled the criteria of creativity. Data analysis was performed in several stages as follows: 1) analyzing the interview data and the learning videos; 2) performing data reduction by making abstractions; 3) organizing the data in units that were then categorized by coding; 4) checking the data validity by doing time triangulation; 5) analyzing interesting phenomena that are associated with the participant's creativity. The results of the analysis showed that the subject's creativity was demonstrated through cognitive flexibility and cognitive fluency, indicated by repeated or cyclic cognitive processes before the participant discovered the solution to the problem. It can be concluded that both synchronous and asynchronous learning methods can support the development of college students' creativity during the covid-19 pandemic.
\end{abstract}

Keywords: Covid-19 pandemic; creativity; synchronous and asynchronous learning.

\begin{abstract}
Abstrak
Wabah virus corona memaksa semua perguruan tinggi untuk melakukan pembelajaran secara online menggunakan internet. Kami telah mempertimbangkan untuk mengembangkan kreativitas siswa melalui pembelajaran online. Oleh karena itu, kami menerapkan pembelajaran synchronous dan metode pembelajaran asynchronous di kelas dan mengamati bagaimana metode ini mempengaruhi kreativitas siswa. Teknik purposive sampling digunakan untuk memilih satu dari 40 mahasiswa Jurusan Pendidikan Matematika STKIP YPUP untuk berpartisipasi dalam penelitian ini. Subjek dipilih karena telah memenuhi kriteria kreativitas. Analisis data dilakukan dalam beberapa tahapan sebagai berikut: 1) menganalisis data wawancara dan video pembelajaran; 2) melakukan reduksi data dengan membuat abstraksi; 3) mengorganisasikan data dalam satuan-satuan yang kemudian dikategorikan dengan pengkodean; 4) pengecekan keabsahan data dengan melakukan triangulasi waktu; 5) menganalisis fenomena menarik yang terkait dengan kreativitas peserta. Hasil analisis menunjukkan bahwa kreativitas subjek ditunjukkan melalui keluwesan kognitif dan kelancaran kognitif, yang ditunjukkan dengan proses kognitif berulang atau siklik sebelum partisipan menemukan solusi dari masalah. Disimpulkan bahwa metode pembelajaran synchronous dan asynchronous dapat mendukung pengembangan kreativitas mahasiswa selama masa pandemi covid-19.
\end{abstract}

Kata Kunci: Pandemi Covid-19, Kreativitas, Pembelajaran Synchronous dan Asynchronous 
DOI: https://doi.org/10.24127/ajpm.v10i3.3897

\section{INTRODUCTION}

Since COVID-19 has spread across China and around the world, causing more than 70.000 deaths. Experts attributed the outbreak to the new coronavirus (COVID-19) (Li et al., 2020). The novel corona virus (nCoV) is a new strain that has not been previously identified in humans. World Health Organization (2020) defines coronavirus as a large family of viruses that cause illness, ranging from the common cold to more severe illnesses, such as MERS-CoV and SARSCoV (Memish et al., 2020).

Consequently, to prevent the spread of COVID-19, especially in Indonesia. In this context, the Ministry of Education and Culture together with the Ministry of Health, the Ministry of Home Affairs, and the Ministry of Religious Affairs has issued a Joint Decree $(S K B)$ on converting face-toface learning to distance learning $(P J J)$, both online and offline. Online learning, which has been encouraged since 1980, has finally returned to its current momentum. The covid-19 pandemic has forced all parties to carry out learning activities in higher education using the internet through online lectures (Adedoyin \& Soykan, 2020; Li et al., 2020; Özdin \& Bayrak Özdin, 2020).

To help overcome time constraints, particularly in the preparation of learning content, teachers must use thousands of Open Educational Resources (OER) published and available in national and international repositories. Open Educational Resources (OER) in UNESCO's recent recommendation refers to learning, teaching, and research materials (Huang et al., 2020). Bliss et al. (2013) also state that using OER can help teachers save time in preparing learning materials.
To solve problems related to teacher or student isolation, teachers must develop OER-based learning and ask students to find content in solving problems (Huang et al., 2020). Teachers can take advantage of OER by accessing the materials. Sites that can accommodate online learning include Google Classroom, Edmodo, Quipper, Zenius, Kelaskita, Brainly, Bimbel Smart, Whatsapp, Zoom, and etc.

The use of online learning can indeed be said to be the best choice during a pandemic. However, in view of students' need for in the form of mastery of 21 st century skills and one of the skills in the 21 st century that must be developed in a student is creativity (Colby \& Ortman, 2015). Unfortunately, very few studies have proven that online learning can improve students' creativity (Colby \& Ortman, 2015). Hence, there needs to be further discussion regarding the influence of online learning with needs. If it is not effective, then it can be used as a basis for further improvements.

The importance of creativity was stated by several psychologists Aldig \& Arseven (2017); De Bono (2015), that a rapidly changing world requires individuals to develop adaptive skills. Therefore, every country needs individuals who are able to use information properly, produce information and have creativity. Creative thinking skills are a factor that will support children's creativity, which produces excellent human resources with high productivity (De Bono, 2015; Karaca et al., 2020; Wojciehowski \& Ernst, 2018).

A number of researchers have intensively studied how a teacher can increase the creativity of a student (Corfman \& Beck, 2019; Sirajuddin et al., 2020). Furthermore, Corman argued that developing student creativity 
requires teachers to have knowledge of what creativity is and what it looks like (Parsons et al., 2015). Beghetto \& Kaufman (2013) proposed that instructors who were required to teach creativity while lacking deep understanding of what creativity is might be doing more damage than good. This statement suggests that teacher needs to understand 5 important principles of creativity. There are novelty, levels of creativity, environmental factors that can inhibit or stimulate creativity, fluency, and originality.

Researchers have formulated the design of online learning that is effective to develop students' creativity. Unlike the conventional learning methods known so far, online learning is divided into two types or methods. The first online learning method is synchronous learning, which occurs or applies at the same time or simultaneously (Coy et al., 2014; Hjalmarson, 2017; Rogers et al., 2021). Synchronous learning is a learning process carried out by lecturers and students at the same time so that it allows direct interaction either via the internet or the Intranet. This method is often referred to as a virtual classroom because the class is virtual and the participants are spread all over the archipelago or around the world and are connected via the internet. The opposite of synchronous learning is asynchronous learning, which means that learning does not occur at the same time. This method is independent of time, where all users can access a system and communicate according to a flexible schedule. This method provides students and the lecturer with an advantage where teaching materials can be accessed at anytime and from anywhere and learning does not necessarily involve direct interaction between the lecturer and the students. The most widely used online learning method is asynchronous discussion (Guo \& Wei, 2019; Nandi et al., 2012).

In this study, we used both online learning methods, namely synchronous learning and asynchronous learning. The applications used were google classroom, telephone or live chat, zoom or whatsapp group. In addition, students also used learning books and learning materials that had been developed previously. After implemen-ting online learning for one semester, we would evaluate the development of students' creativity in terms of cognitive flexibility and cognitive fluency (Rahayuningsih et al., 2019; Singer \& Voica, 2015). Students were considered to be creative if they were able to complete the project by meeting the indicators of cognitive flexibility and cognitive fluency. Cognitive flexibility includes the ability to describe a variety of problem solving and provide more than one answer to a problem. Cognitive fluency includes the ability to interpret answers, provide feedback, present work fluently and accurately without obstacles. Therefore, the objective of this study observed how these synchronous learning and asynchronous learning methods influenced students' creativity.

Therefore, the general objective of this study is to observe the creativity of students after the implementation of synchronous and asynchronous online learning. Whereas, specific objectives, including (1) How is students' cognitive flexibility after the implementation of synchronous asynchronous learning? and (2) How is students' cognitive fluency after the implementation of synchronous and asynchronous learning? 
DOI: https://doi.org/10.24127/ajpm.v10i3.3897

\section{METHODS}

The purposive sampling technique by Yin (2014) was adapted for this study. The population of this study consisted of two classes of foursemester Mathematics Education students at STKIP YPUP. The subject was selected from three students who had fulfilled the criteria of creative individuals. The selection of the research subject was based on the result of an open-ended essay test that examined the subject's cognitive flexibility and cognitive fluency. Cognitive flexibility refers to the ability to describe a variety of problem solving and provide more than one answer to a problem. Cognitive fluency includes the ability to interpret answers, provide feedback, present work fluently and accurately without obstacles. The subject should also demonstrate good communication skills.

\section{Setting}

In the early of the 2019-2020 even semester, which was in March 2020, learning was conducted online via zoom and Google Classroom alternately according to the material needs to be provided. Learning was carried out to familiarize students with the theoretical framework needed to develop an innovative and creative learning design, where students are able to critically evaluate and describe information visually. Learning was carried out in 9 meetings for one semester. The learning topics included: 1) understanding learning design and the psychological foundation of instructional design; 2) identifying learning needs; 3 ) analyzing learning; 4) analyzing student characteristics; 5) formulating learning objectives; 6) developing an assessment instrument; 7) developing learning strategies; 8) developing learning materials and 9) evaluating learning. Every week, the students were presented with material in the form of video which can be accessed from Google classroom. Then, they were required to work on a project and participate in online discussions using the zoom application that was held in the following week to present the results of the project.

\section{Data collection and analysis}

Data were collected from several sources, namely interview with the research subject and transcripts of online learning conducted through google classroom and zoom. The interview was conducted via Zoom application (https://zoom.us/) following the interview guidelines we had previously developed (Creswell \& Poth, 2018). The interview transcripts were re-read carefully while listening to the recorded interviews to ensure their suitability.

The data were explored by combining structured interviews and unstructured interviews. The research subject was interviewed on 2 June 2020 via Zoom. The interview was recorded and transcribed. The questions posed in the interview are in accordance with the components of creativity, namely cognitive flexibility and cognitive fluency. In addition to the interview transcripts, there were 18 pieces of instructional videos that were included in the data analysis. The data analysis was carried out in the following steps: 1) analyzing and examining all available data from various sources, namely from interview and learning videos; 2) doing data reduction by making abstractions; 3) organize the data in units which were further categorized by coding; 4) checking the validity of the data by means of time 
triangulation; 5) analyzing interesting phenomena related to the subject's creativity that happened during the online learning process, including the unplanned behavior shown by the subject that was not related to the research objectives; 6) interpreting the data or making conclusions.

The early phase of data collection by organizing data units to create coding (categorization)

The data units were organized based on the problem being studied, namely creativity in online learning.
The units studied were based on the Plsek's creative process (Fields \& Bisschoff, 2013). Plsek's developed a creativity model adopted from several creativity models known as The Directed Creativity Cycle, which consists of 1) preparation; 2) imagination; 3) development; and 4) action (Fields \& Bisschoff, 2013). The data in this study were categorized by coding the subject's answers, which are in the form of verbal utterances. The arrangement of the data units is presented in Table 1.

Table 1 . The directed creativity cycle

Term

Preparation Observe and analyze seriously how something can work well or fail pre Imagination Create a series of concepts in memory to generate new ideas. ima

Development Build new ideas and implement them in problem solving. dev

Action Implement the ideas and test the solutions.

act
The next categorization relates to the creativity components that were identified during the learning process and the presentation of project tasks. These components are cognitive flexibility and cognitive fluency (Rahayuningsih et al., 2019; Singer \& Voica, 2015). The coding of the components is presented in Table 2 .

Tabel 2. The coding of components

\begin{tabular}{llc}
\hline \multicolumn{1}{c}{ Term } & \multicolumn{1}{c}{ Definition } & Code \\
\hline $\begin{array}{l}\text { Cognitive } \\
\text { flexibility }\end{array}$ & $\begin{array}{l}\text { Demonstrate the ability to describe various solutions and } \\
\text { provide more than one answer to a problem. }\end{array}$ & Cfx \\
$\begin{array}{l}\text { Cognitive } \\
\text { fluency }\end{array}$ & $\begin{array}{l}\text { Demonstrate the ability to interpret answers, provide } \\
\text { feedback, present work fluently and precisely without } \\
\text { obstacles. }\end{array}$ & Cfl \\
\hline
\end{tabular}

\section{RESULTS AND DISCUSSION Results}

The results of this study are described qualitatively and the results of the data analysis are presented based on the keywords contained in the research question. The research question is how is the creativity of students after the implementation of synchronous and asynchronous online learning during the Covid-19 outbreak?

To answer the research question, we first calculated the number of comments provided by the research subject relating to the components of creativity, namely cognitive flexibility and cognitive fluency. The number of comments relating to the components of creativity is presented in Table 3 . 
DOI: https://doi.org/10.24127/ajpm.v10i3.3897

Table 3. Number of comments relating to the components of creativity

\begin{tabular}{lc}
\hline $\begin{array}{c}\text { Components of } \\
\text { Creativity }\end{array}$ & $\begin{array}{c}\text { Number of } \\
\text { Comments }\end{array}$ \\
\hline Cognitive flexibility & 20 \\
Cognitive fluency & 14 \\
Total & 34 \\
\hline
\end{tabular}

\section{Cognitive flexibility in the creative process}

Being able to find various solutions to a problem is an indicator of cognitive flexibility. We asked the subject several open-ended questions associated with the learning materials that have been discussed in class. In the interview, the research subject was able to deliver his arguments clearly in accordance with what was on his mind. The subject's cognitive flexibility can be seen in the 1st, 3rd and 6th week of the lesson. There were 20 items of cognitive flexibility observed. Following excerpt is taken from the interview between the researcher $(\mathrm{P})$ and the subject.

P: What do you know about instructional design?

S: Design refers to a process, instructional design means an organized procedure which includes the steps of analyzing, designing, developing, implementing and assessing learning.

$P$ : Is there any other description about instructional design? Why is it important to design learning?

$S$ : carried out to realize learning. Designing learning is important because, the meaning, direction and goals of learning can be clearly planned; Second, it can lead teachers to conduct systematic activities. Thinking systematically is thinking sequentially, so that through clear and definite steps, learning results will be optimal; Third, in designing learning, all available potentials and resources must be optimized; and Fourth, by designing learning, we can find out whether the learning objectives have been achieved or not and then provide feedback for it.

$P$ : In your opinion, do you think teachers face difficulty designing learning during the pandemic?

$P$ : Because design means process. Therefore, instructional design can also be interpreted as the stages that are

$S: \quad$ One that can be applied is blended learning, which is learning through content and instructions submitted online. Many applications can be used to design interesting and interactive learning.

$P$ : How did you obtain the information about it?

S : I am a student, so I have to actively search for information from various learning sources. Besides books or lecturers' explanations, social media such as Twitter, Facebook, and Instagram also provide abundant information.

From the interview excerpt, it is obvious that the subject was able to describe various alternative answers fluently and tried to make the interviewer understand what he was explaining. The research subject also described the questions neatly and straightforwardly. The verbal skills possessed by the subject greatly support his creative abilities, especially cognitive flexibility.

There were several processes the subject went through when describing his opinion whenever the interviewer asked an open question. The first stage is called the preparation (pre) stage. At this stage, the subject repeated the interview questions many times, then paused between these questions while thinking about the answers to be 
expressed. At this stage, the subject looked quite nervous and anxious, although when explaining the answer, he showed great enthusiasm and presented his argument fluently. The second stage is called the imagination (ima) stage. At this stage, the subject demonstrated the ability to identify problems by repeating the questions given by the interviewer. The third stage is the development (dev) stage. At this stage, the subject delivered his points fluently then repeated the questions from the interviewer. This continued to happen until the subject was able to present the answer in good and straightforward language. At the action (act) stage, the subject showed the ability to collect information from various sources. The subject appeared to be able to describe the name of the learning resources that he usually accessed even though he did not specify what kind of information that could support his understanding of the materials.

\section{Cognitive fluency in the creative process}

The ability to interpret answers, provide feedback, present work fluently and accurately without any obstacles is called cognitive fluency. This ability was demonstrated by the subject when the interviewer asked questions. Every question was answered and supported by a rational opinion related to the subject's experience while being a student. A given project was sometimes not included in the book or information the subject had received before, thus, the cognitive fluency of the subject can be clearly identified. The subject's cognitive fluency was observed in the first, second, fourth and seventh week with a total items of 14 . The following is an excerpt from the interview between the researcher (P) and the subject (S) which was conducted at week 7 .

P: What is your thought on children with special needs?

$S$ : I've heard the term, is it those with physical and mental disabilities?

$P$ : Can you give your opinion on that?

$S$ : I think they are children who need more special attention than children in general. Their strengths must be emphasized, so that their physical deficiencies are invisible.

$P$ : Why do they need special attention? Can you explain?

$S$ : Because they are special. Every child has the right to education, including children with special needs.

$P: \quad$ In your opinion, what are the obstacles for a teacher during the covid-19 pandemic to continue providing proper education for children with special needs? Can you explain?

$S: \quad$ The problem is the unpreparedness of children and parents at home. Parents feel unprepared for this kind of situation. Therefore, it is hoped that there will be good cooperation between parents and teachers so that they can provide proper learning for the children in the midst of the pandemic.

P: What made you draw such conclusion?

S: I am motivated to get to know children with special needs more closely, because my family environment is almost filled with special children like that. I have a strong emotional bond with them.

In the above interview, the subject demonstrated cognitive fluency. Cognitive fluency originates from a sensitivity to the situation at hand. The subject saw a problem in the situation 
DOI: https://doi.org/10.24127/ajpm.v10i3.3897

that must be resolved immediately. Furthermore, there was an element of authenticity in the subject's idea which is related to his background knowledge. The subject felt that he needed to study more about children with special needs so that he could understand them better.

In the preparation process, the subject was able to relate information freely, carry out the imagination process in each situation, generate new and different ideas, and pay attention to intuition. Guessing and connecting are the two processes that can be identified when the subject was elaborating his argument. There was a cyclic creative process. The cyclic creative process means a process that does not have to be passed sequentially, but sometimes the process rotates at that point only. This process eventually brought the subject to the point where he could express his opinions naturally. The creative process of the subject that occurred in the 7th week only consisted of the preparatory (pre), the imagination (ima) and action (act) stages. The subject showed a relaxed attitude when answering all the interview questions. Sometimes the subject looked restless when the interviewer attempted to dig up more information by provoking more specific questions. The following is an excerpt from the interview of the researcher $(\mathrm{P})$ with the subject (S) at week 4.

\section{P: What do you know about attitude assessment?}

S: Attitude assessment consists of assessing one's attitude towards God or the creator and one's attitude towards God's creatures. These two components must be included in the attitude assessment.

$P$ : Do you think attitude assessment is important?

S: Assessment should be carried out fairly and thoroughly. Assessment targets the learning process and learning outcomes that include insights into the knowledge, attitude, and social skills that have been achieved by students. So far, the assessment has only been done partially, that is, it only focuses on the knowledge aspect, but the attitude aspect which is crucial in supporting character education is not much involved in the assessment process. The assessment should be carried out in a balanced manner by involving all aspects of student abilities, so that the results of the assessment can describe the ability or learning achievement of students as a whole. By all means, I consider that it is important to develop attitude assessments in schools.

P: $\quad$ What kind of attitude assessment would you develop?

Based on the interview excerpt, it can be seen that the subject only answered according to what he knew, but when he was asked to answer another question, he said "I'll think about it later". Therefore, it is considered that the subject did not go through the development process (dev). The statement "I'll think about it later" implies a process of imagination (ima) which only lasted temporarily, because the subject immediately conducted the action (act) process without going through the development (dev) stage.
P : Do you enjoy learning from home using this online method?
$S$ : $\quad$ This is very fun, I have a lot of time to complete the tasks without outside with my friends. thinking about spending time
$P$ : Will you share your learning experiences during the pandemic?
$S: \quad B e s i d e s$ having a lot of time doing my college assignments, I also 
DOI: https://doi.org/10.24127/ajpm.v10i3.3897

spend a lot of time relaxing with my family. We hardly have time together, but when the pandemic started, my mother who used to be a busy woman is now always there to guide me to do my assignments. This is one of the positive experiences I have had only during the pandemic.

The interview excerpt illustrates that the subject has been constantly motivated and enjoyed learning with the online discussion model, so that the obstacles in learning were not too visible. When we asked further about the negative side related to learning during the pandemic, the subject only answered, "I am only worried if I contract the corona virus and must be hospitalized". Data analysis has revealed that the creative processes that the subject went through were the creative processes suggested (Jaarsveld et al., 2015; Rosso, 2014). Puspitasari et al. (2018) developed a creative thinking model that was adopted from some of the creative thinking models proposed by past studies. The creative thinking model that has been developed by Plesek is known as The Directed Creativity Cycle, which consists of 1) preparation 2) imagination 3) development 4) action. Plesek argues that the creative thinking processes proposed by previous experts tends to imply the birth of creative ideas from the thinker's subconscious mind and these ideas are largely out of the thinker's control. Furthermore, Plesek argues that the birth of new ideas from the thinker requires strong encouragement from outside. The thinker should not just imagine new ideas but have to try hard to implement the ideas in real life.
The subject's creative processes were characterized by cognitive flexibility and cognitive fluency. Singer \& Voica (2015) uses organizational theory of creativity as an indicator of student creativity in terms of cognitive flexibility. Furthermore, Singer explains that when a student is able to think flexibly, he is able to pose new and varied problems (cognitive novelty and cognitive variety), change the frame of mind in solving problems, as well as identify/discover new ones (change in cognitive framing). In line with Singer's opinion, Rahayuningsih et al. (2019) states that in addition to cognitive flexibility, cognitive fluency indicates that someone is creative. Cognitive fluency is the ability to provide good and reasonable solutions.

\section{Discussion}

The results of this study indicate that the creative processes that the subject went through are not always sequential, but sometimes repetitive or cyclic in nature. The subject sometimes faced a "dead end" when faced with a problem, which required him to repeat the process that had been passed to draw a conclusion. This finding is supported by Ayllon et al. (2016); Schoevers et al. (2019); Sitorus \& Masrayati (2016), that creative processes can encourage a person to carry out mental activities and seek coherence between learning experiences and the problem at hand, so that the person does not yet have consistent awareness in solving problems, and is more likely to use more practical techniques or applications.

This study also shows that online learning can help improve skills that lead to a creative process, and increase motivation to learn. In line with these findings, Corfman \& Beck (2019) has 
concluded that the student-to-instructor interaction in asynchronous online discussions could promote domainrelevant skills, and encourage creativity-relevant processes, and increase task motivation. This statement is also confirmed by Akyol \& Garrison (2011) who state that the student-to-instructor interaction in asynchronous online discussions is one of the alternatives to help students integrate their ideas.

During the online learning practices, the subject showed great enthusiasm for engaging in online discussions. He tried to answer all questions properly. This indicates that learning through online media can improve students' ability to solve a problem. The ability to complete a project and present the results smoothly was seen when the subject conducted online learning with synchronous and asynchronous methods. The student was able to answer any question by providing logical and rational reasons. (Hargrove, R \& Nietfeld, 2019) emphasizes that problem solving is the most important part of creativity. Furthermore, Weisberg (2007) underlines that for problem solving to take place, the situation must be novel for the person, and the person must devise a sequence of "moves" that changes an unsatisfactory situation ("the problem state") into the desired state (the "goal"). The project presented in this study was challenging for the student so that he felt challenged to complete the project in a unique or unusual way. The creative tasks that are challenging for students often begin with elements of play and fun, and the tasks are relevant to immediate learning goals as well as longer-term life goals. Students are not only grounded in their disciplinary culture and domain knowledge, but in creative learning approaches, enabling them to better meet a complex and "unknown future" (Barnett, 2012). In addition, the subject also submitted the project and the project presentation results in a timely manner to the lecturer. Automation in the online learning system does not compromise late submissions. Thus, it can be seen that online learning with synchronous learning and asynchronous learning methods is able to develop students' creativity. The student-tostudent interaction in asynchronous online discussions can demonstrate best practices in teaching online courses by allowing students to integrate ideas (Akyol \& Garrison, 2011).

\section{CONCLUSIONS AND SUGGESTIONS}

The results of the study showed that the subject underwent creative processes suggested by Plesek, which consisted of 1) preparation 2) imagination 3) development 4) action. The creative processes were characterized by the subject's cognitive flexibility dan cognitive fluency. The creative processes undergone by the subject were not always in sequential, rather they were repeated or cyclic in nature. Sometimes, the subject faced a dead end when faced with a problem. Thus, he was forced to repeat the same process again to draw a conclusion. This study also shows that online learning can support the development of skills that help students improve creativity and motivation in learning.

This study was carried out over a long period of time that caused saturation for the subject. Thus, it is sometimes difficult for the subject to express what he was thinking while completing the project. Therefore, it is also difficult for us to describe the cognitive processes that occurred at that time. In this study, the subject was selected using the criteria-based 
selection technique which was based on the assumption that the subject was the main actor in this study. Therefore, we suggest that it is important to be extra careful in selecting research subjects because the quality of data highly depends on the research subjects. Besides, research subjects should also be able to describe the situation that the researcher expects.

Interviews with the subject were conducted via Zoom, so it was difficult for us to observe the subject's gestures in detail, which might provide important information related to the objective of the study. Since it was impossible to conduct interviews with other people in different places, we had to revise the transcripts to explore more information.

There was only one student involved as a subject in this study. This student was selected from 40 potential subjects. In the preliminary stage, four students fulfilled the criteria of creative individuals, but three subjects were difficult to track. Nevertheless, the one subject was able to provide sufficient information. He also had good communication skills which were also considered as one of the requirements to select the subject.

\section{REFERENCES}

Adedoyin, O. B., \& Soykan, E. (2020). Covid-19 pandemic and online learning: the challenges and opportunities. Interactive Learning Environments, O(0), 113.

https://doi.org/10.1080/10494820. 2020.1813180

Akyol, Z., \& Garrison, D. R. (2011). Understanding cognitive presence in an online and blended community of inquiry: Assessing outcomes and processes for deep approaches to learning. British

Journal of Educational
Technology, 42(2), 233-250.
https://doi.org/10.1111/j.1467-
8535.2009.01029.x

Aldig, E., \& Arseven, A. (2017). The Contribution of Learning Outcomes for Listening to Creative Thinking Skills. Journal of Education and Learning, 6(3), 41.

https://doi.org/10.5539/jel.v6n3p4 1

Ayllon, M., Gomez, I., Ballesta-Claver, \& Julio. (2016). Mathematical thinking and creativity through mathematical problem posing and solving. Propósitos y Representaciones, 4(1), 169-218. https://eric.ed.gov/?id=EJ1126306

Barnett, L. A. (2012). Playful People: Fun is in the Mind of the Beholder. Imagination, Cognition and Personality, 31(3), 169-197. https://doi.org/10.2190/IC.31.3.c

Beghetto, R. A., \& Kaufman, J. C. (2013). Fundamentals of creativity. Educational Leadership, 70(5), 10-15.

Bliss, T., Robinson, T. J., Hilton, J., \& Wiley, D. A. (2013). An OER COUP: College Teacher and Student Perceptions of Open Educational Resources. Journal of Interactive Media in Education, 2013(1), 4. https://doi.org/10.5334/2013-04

Colby, S. L., \& Ortman, J. M. (2015). Projections of the Size and Composition of the U.S. Population: 2014 to 2060 . Program, 3, 1-13.

Corfman, T., \& Beck, D. (2019). Case study of creativity in asynchronous online discussions. International Journal of Educational Technology in Higher Education, 16(1), 22. 
DOI: https://doi.org/10.24127/ajpm.v10i3.3897

https://doi.org/10.1186/s41239-

019-0150-5

Coy, K., Marino, M. T., \& Serianni, B. (2014). Using Universal Design for Learning in Synchronous Online Instruction. Journal of Special Education Technology, 29(1), 63-74. https://doi.org/10.1177/01626434 1402900105

Creswell, J. W., \& Poth, C. N. (2018). Creswell, John W (pp. 1-459).

De Bono, E. (2015). Lateral Thinking: A Textbook of Creativity. In Penguin Books (Vol. 3). Penguin Group.

Fields, Z., \& Bisschoff, C. A. (2013). A Theoretical Model to Measure Creativity at a University. Journal of Social Sciences, 34(1), 47-59. https://doi.org/10.1080/09718923. 2013.11893117

Guo, W., \& Wei, J. (2019). Correction to: Teacher Feedback and Students' Self-regulated Learning in Mathematics: A Study of Chinese Secondary Students (The Asia-Pacific Education Researcher, (2019), 28, 3, (265275), 10.1007/s40299-019-004348). Asia-Pacific Education Researcher, 28(3), 277. https://doi.org/10.1007/s40299019-00436-6

Hargrove, R \& Nietfeld, J. (2019). The Impact of Metacognitive Instruction on Creative Problem Solving. Journal of Chemical Information and Modeling, 53(9), $1-48$.

Hjalmarson, M. A. (2017). Learning to teach mathematics specialists in a synchronous online course: a selfstudy. Journal of Mathematics Teacher Education, 20(3), 281301. https://doi.org/10.1007/s10857-
015-9323-X

Huang, R., Tlili, A., Chang, T.-W., Zhang, X., Nascimbeni, F., \& Burgos, D. (2020). Disrupted classes, undisrupted learning during COVID-19 outbreak in China: application of open educational practices and resources. Smart Learning Environments, $7(1), \quad 19$. https://doi.org/10.1186/s40561020-00125-8

Jaarsveld, S., Fink, A., Rinner, M., Schwab, D., Benedek, M., \& Lachmann, T. (2015). Intelligence in creative processes: An EEG study. Intelligence, 49, 171-178. https://doi.org/10.1016/j.intell.201 5.01 .012

Karaca, N. H., Uzun, H., \& Metin, Ş. (2020). The relationship between the motor creativity and peer play behaviors of preschool children and the factors affecting this relationship. Thinking Skills and Creativity, 38(August), 100716. https://doi.org/10.1016/j.tsc.2020. 100716

Li, J., Yang, Z., Qiu, H., Wang, Y., Jian, L., Ji, J., \& Li, K. (2020). Anxiety and depression among general population in China at the peak of the COVID- 19 epidemic. World Psychiatry, 19(2), 249250.

https://doi.org/10.1002/wps.20758

Memish, Z. A., Perlman, S., Van Kerkhove, M. D., \& Zumla, A. (2020). Middle East respiratory syndrome. The Lancet, 395(10229), 1063-1077. https://doi.org/10.1016/S01406736(19)33221-0

Nandi, D., Hamilton, M., \& Harland, J. (2012). Evaluating the quality of interaction in asynchronous discussion forums in fully online 
DOI: https://doi.org/10.24127/ajpm.v10i3.3897

courses. Distance Education, 33(1), 5-30. https://doi.org/10.1080/01587919. 2012.667957

Özdin, S., \& Bayrak Özdin, Ş. (2020). Levels and predictors of anxiety, depression and health anxiety during COVID-19 pandemic in Turkish society: The importance of gender. International Journal of Social Psychiatry, 66(5), 504511.

https://doi.org/10.1177/00207640 20927051

Parsons, S., Guldberg, K., PorayskaPomsta, K., \& Lee, R. (2015). Digital stories as a method for evidence-based practice and knowledge co-creation in technology-enhanced learning for children with autism. International Journal of Research \& Method in Education, 38(3), 247-271.

https://doi.org/10.1080/1743727X .2015 .1019852

Puspitasari, L., In'am, A., \& Syaifuddin, M. (2018). Analysis of Students' Creative Thinking in Solving Arithmetic Problems. International Electronic Journal of Mathematics Education, 14(1), 49-60.

https://doi.org/10.12973/iejme/39 62

Rahayuningsih, S., Nusantara, T., As, A., \& Susanto, H. (2019). Cognitive Styles: Characterization of College Students' Creative Mathematical Thinking. International Journal of Humanities, Social Sciences and Education, 6(3), 50-60. https://doi.org/10.20431/23490381.0603007

Rogers, K. S., Thomas, C., \& Holmes, H. (2021). Encouraging student participation in mathematical activities in synchronous online tuition. Open Learning: The Journal of Open, Distance and eLearning, $\quad 00(00), \quad 1-17$. https://doi.org/10.1080/02680513. 2021.1938523

Rosso, B. D. (2014). Creativity and Constraints: Exploring the Role of Constraints in the Creative Processes of Research and Development Teams. Organization Studies, 35(4), 551585.

https://doi.org/10.1177/01708406 13517600

Schoevers, E. M., Leseman, P. P. M., Slot, E. M., Bakker, A., Keijzer, R., \& Kroesbergen, E. H. (2019). Promoting pupils' creative thinking in primary school mathematics: A case study. Thinking Skills and Creativity, 31(October 2018), 323-334. https://doi.org/10.1016/j.tsc.2019. 02.003

Singer, F. M., \& Voica, C. (2015). Is problem posing a tool for identifying and developing mathematical creativity? Mathematical Problem Posing: From Research to Effective Practice, December 2014, 141174. https://doi.org/10.1007/9781-4614-6258-3_7

Sirajuddin, S., Sa'dijah, C., Parta, N. I., \& Sukoriyanto. (2020). Multirepresentation raised by prospective teachers in expressing algebra. Journal for the Education of Gifted Young Scientists, 8(2), 857-870.

https://doi.org/10.17478/jegys.688 710

Sitorus, J., \& Masrayati. (2016). Students' creative thinking process stages: Implementation of 
DOI: https://doi.org/10.24127/ajpm.v10i3.3897

realistic mathematics education. Thinking Skills and Creativity, 22, 111-120.

https://doi.org/10.1016/j.tsc.2016. 09.007

Weisberg, R. (2007). Robert W. Weisberg " Creativity. Understanding innovation in problem solving, science, invention, and the arts ."

Wojciehowski, M., \& Ernst, J. (2018). Creative by Nature: Investigating the Impact of Nature Preschools on Young Children's Creative Thinking. International Journal of Early Childhood Environmental Education, 6(1), 3-20. https://files.eric.ed.gov/fulltext/EJ 1193490.pdf

World Health Organization. (2020). Laboratory testing for 2019 novel coronavirus (2019-nCoV) in suspected human cases. WHO Interim Guidance, 2(March), 110.

Yin, R. K. (2014). Case study research: Design and methods (5th ed.). Thousand Oaks, CA: Sage. 